\title{
INTERFACIAL ENZYME PARTITIONING AS A TOOL FOR CONSTRUCTING BIOSENSORS
}

\author{
N. ADÁNYI, J. SZAMOS, E. E. SZABÓ and M. VÁRADI \\ Central Food Research Institute, H-1022 Budapest, Herman Ottó út 15. Hungary
}

(Received: 17 March 1999; accepted: 24 June 1999)

To explore new possibilities of enzyme immobilization, we investigated bioactive layers prepared by a new procedure based on three-phase partitioning (TPP) of proteins. By this method a third phase or midlayer as a protein layer can be developed at the interface of a protein system containing two phases (organic solvent/aqueous salt solution). Proteins of meat origin partitioned together with bioselective material (e.g. an enzyme) after centrifugation resulted in excellent bioactive layers.

In the newly developed sensor, glucose oxidase was immobilized in a layer, which was fixed on the surface of a platinum ring electrode. The biosensor was built in a flow injection analyzer (FIA) system, where the hydrogen peroxide generated during the enzymatic reactions was determined by an amperometric cell. The parameters for biochemical and electrochemical reactions (ion concentration and $\mathrm{pH}$ of buffer, flow rate) were optimized. The linear range of analysis by the newly developed sensor was from 0.5 to $10 \mathrm{mmol} \mathrm{l}^{-1}$ glucose. The biosensor could be used for more than 300 analysis.

Keywords: bioactive protein gel layer, three phase partitioning, amperometric cell, FIA system

When planning a new method for constructing biosensors, the most important question is how to immobilize the enzyme/enzymes or cells so that the biochemicalelectrochemical reactions be complete without the disturbing agents reaching the surface of the electrode. One of the most important requirements in a new method used in online processes is the easy and reproducible preparation of enzyme layer. Entrapment in polymeric gels prevents diffusion of biomolecules to the reaction mixture. On the other hand, small substrates can easily permeate. The gel entrapment is a mild procedure, the biomolecules are not covalently bound to the matrix. Contrary to gel entrapment, covalent binding is often accompained by loss of activity.

Slices of animal tissues or plant origin are the most complex biosystems applied so far in biosensors. Tissues containing large amounts of the enzymes of interest have been widely used. This sensor benefits from the high stability in its native environment. Fitting into the trend towards improvement of availability and simplification of the 
preparation of biocatalytic layers for biosensors, the use of crude materials has been explored (SCHELLER \& SCHUBERT, 1992).

Three-phase partitioning (TPP) used in this work to prepare protein layers is originally a protein enrichment method, in which proteins are collected in form of a middle layer between aqueous (ammonium sulfate solution) and organic (tert-butanol) phases at room temperature (ODEGAARD et al., 1984; LOVRIEN et al., 1987; SZAMOS \& HOSCHKE, 1992). PIKE and DENNISON (1989) investigated the partitioning process for several proteins, however details of the mechanism are unknown.

An analytical application of TPP for drips (multicomponent meat protein solutions, SZAMOS et al., 1998) was used for developing a method to prepare protein layers of definite size. To prepare drips the centrifugal method of PENNY (1975) was used with modifications. Solutions having an initial interfacial tension of $1 \mathrm{mN} \mathrm{m}^{-1}$ were used in each case for three phase partitioning. Consistency of these layers proved to be suitable for biosensors, so an enzyme in a solution preserving its activity during the partitioning process could be loaded into the system recovering in the layer by centrifugation. We used glucose oxidase (GOD) to investigate whether this method is acceptable as a new immobilization process for biosensor technology.

\section{Instrumentation and materials}

\subsection{Materials and reagents}

Glucose oxidase (EC. 1.1.3.4): $25 \mathrm{U} \mathrm{mg}^{-1}$, lyophilized from Aspergillus niger and tert-butanol (HPLC grade) were obtained from Sigma (St. Louis, MA, USA).

All other reagents were commercially available and of analytical grade.

\subsection{Instrumentation}

A flow injection analyzer (FIA) consisting of a buffer reservoir, a peristaltic pump (Minipuls 3, Gilson Co., Villiers-le-Bel, France), an injection valve (20 $\mu 1$ sample loop, Rheodyne Inc., Cotati, CA, USA) and an amperometric cell connected to polarograph (Radelkis, Budapest, Hungary) was the basic instrumentation of our research. A platinum-ring electrode was used as measuring electrode while the reference electrode was a silver/silver chloride $(\mathrm{Ag} / \mathrm{AgCl})$ electrode. The polarization potential was ensured and fixed $(+600 \mathrm{mV})$.

The protein layers were washed in a buffer solution and fixed on the electrode surface with a nylon net and connected to the flow-through amperometric cell (Fig. 1). The layers were easy to change after cleaning the Pt-ring electrode. 


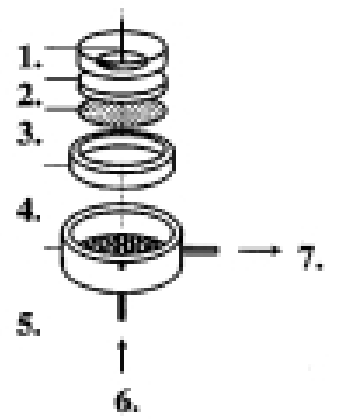

Fig. 1. Construction of biosensors, 1: Platinum-ring electrode, 2: protein layer with GOD, 3: nylon net, 4: seal, 5: plexi block, 6: inlet, 7: outlet

\subsection{Preparation of protein layers}

Pieces of meat (leg of pork, chicken and turkey, rump of beef) of $2 \mathrm{~cm}$ in diameter were cut out by a stainless steel cork-borer from 1-2 cm thick slices. Instead of Teflon discs perforated with channels (PENNY, 1975), glass beads (4 mm diameter) were used as holder in $50 \mathrm{ml}$ Falcon tubes filled up to $7.5 \mathrm{ml}$. Meat discs were placed on beads and centrifuged (Beckman J2-21, JS-7.5 swinging bucket rotor) at $450 \mathrm{~g}$ for $20 \mathrm{~min}$ at $15{ }^{\circ} \mathrm{C}$. The spun drip from the meat was collected by Finnpipette, freezedried, and then kept at room temperature.

Lyophilized drips were suspended in distilled water. Aliquots of $50 \mu \mathrm{l}$ were added to $950 \mu \mathrm{l}$ ammonium sulfate solution in screw capped $2 \mathrm{ml}$ polypropylene tubes at $25^{\circ} \mathrm{C}$ (thermostat). After $20 \mathrm{~min} 310 \mu \mathrm{l}$ tert-butanol was added to each tube, shaken thoroughly by hand, then let to stand for $15 \mathrm{~min}$. The tubes were centrifuged at $4500 \mathrm{~g}$ for $6 \mathrm{~min}$ at $20^{\circ} \mathrm{C}$. The thickness of the protein layers was measured and the concentration of freeze-dried drip was calculated to obtain layers about $1.5 \mathrm{~mm}$ thick. This approach resulted in layers about $1.5 \mathrm{~mm}$ thick with the exception of turkey (Table 1).

\subsection{Preparation of layers containing $G O D$}

Calculated amounts of GOD were added to freeze-dried drips of meat (e.g. for one layer of chicken drip containing $20 \mathrm{U} \mathrm{GOD}, 0.48 \mathrm{mg}$ enzyme and $1.4 \mathrm{mg}$ drip were weighed) and suspended in $50 \mu \mathrm{l}$ distilled water. This solution was added to $950 \mu \mathrm{l}$ of ammonium sulfate solution, then processed by the above procedure. The layers containing GOD can be stored in refrigerator for two months. 
Table 1

Change in the thickness of the layer with changing the initial drip concentration

\begin{tabular}{lcccc}
\hline & Beef & Pork & Chicken & Turkey \\
\hline mg drip ml $^{-1}$ & 5.0 & 5.0 & 5.0 & 5.0 \\
Thickness, $\mathrm{mm}^{-1}$ & 3.0 & 5.0 & 5.0 & 4.0 \\
mg drip ml $^{-1}$ & 1.7 & 1.3 & 1.4 & 1.3 \\
Thickness, $\mathrm{mm}$ & 1.0 & 1.5 & 1.5 & 0.5 \\
\hline
\end{tabular}

\section{Results and discussion}

\subsection{Characteristics of the protein layers}

Equidimensional protein layers of $1.0-1.2 \mathrm{~mm}$ thickness and $54 \mathrm{~mm}^{2}$ cross section were prepared from drip of beef, pork, turkey and chicken by TPP, tested for their physical properties, and checked whether they are permeable to hydrogen peroxide.

Protein layers containing GOD were produced using different relative saturation of ammonium sulfate (30,40,50,60\%, respectively) to study the effect of salt concentration and the changes in physical properties. The results are summarized in Table 2. The layers were classified by thickness, permeability for hydrogen peroxide and the signal produced by injected glucose standards ( $\mathrm{pH} 6.0)$.

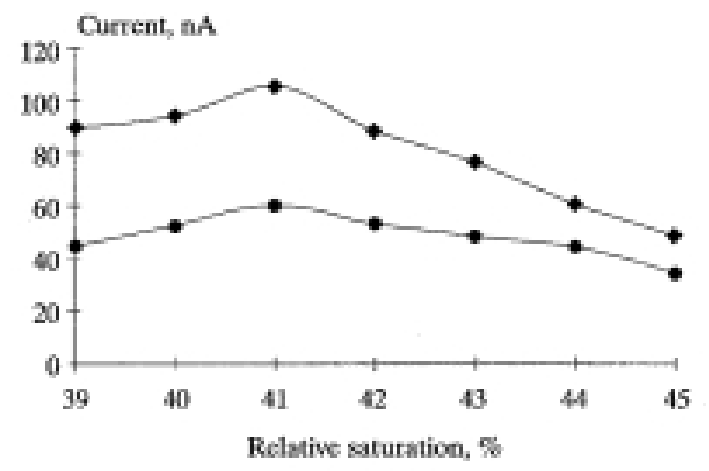

Fig. 2. Effect of relative saturation of ammonium sulfate at TPP (pH 6). •: 5 mmol $1^{-1}$ glucose : $10 \mathrm{mmol} 1^{-1}$ glucose 
Table 2

Properties of protein layers containing GOD using different relative saturations of ammonium sulfate

\begin{tabular}{|c|c|c|c|c|c|}
\hline & \multirow{2}{*}{$\begin{array}{l}\text { Ammonium } \\
\text { sulfate, } \%\end{array}$} & \multirow{2}{*}{$\begin{array}{c}\text { Thickness } \\
\mathrm{mm}\end{array}$} & \multirow{2}{*}{$\begin{array}{c}\mathrm{H}_{2} \mathrm{O}_{2} \\
1 \mathrm{mmol} \mathrm{l^{-1 }} \mathrm{nA}\end{array}$} & \multicolumn{2}{|c|}{ Glucose signal, nA } \\
\hline & & & & $5 \mathrm{mmol} \mathrm{l}^{-1}$ & $10 \mathrm{mmol} \mathrm{l}^{-1}$ \\
\hline \multirow[t]{4}{*}{ Beef } & 30 & 0.5 & 26 & 16 & 28 \\
\hline & 40 & 0.5 & 18 & 20 & 36 \\
\hline & 50 & 1.0 & 16 & 18 & 30 \\
\hline & 60 & 2.0 & - & - & - \\
\hline \multirow[t]{4}{*}{ Turkey } & 30 & 1.5 & 12 & 12 & 28 \\
\hline & 40 & 1.0 & 12 & 16 & 30 \\
\hline & 50 & 1.5 & 12 & 18 & 32 \\
\hline & 60 & 1.0 & 18 & 22 & 40 \\
\hline \multirow[t]{4}{*}{ Chicken } & 30 & 1.5 & 18 & 14 & 30 \\
\hline & 40 & 1.5 & 18 & 30 & 54 \\
\hline & 50 & 2.0 & 16 & 20 & 38 \\
\hline & 60 & 5.0 & - & - & - \\
\hline \multirow[t]{4}{*}{ Pork } & 30 & 0.5 & 2 & 9 & 18 \\
\hline & 40 & 0.5 & 28 & 16 & 36 \\
\hline & 50 & 2.5 & 36 & 38 & 60 \\
\hline & 60 & 5.0 & - & - & - \\
\hline
\end{tabular}

The layers from chicken drip prepared at about $40 \%$ saturation of ammonium sulfate showed acceptable behaviour in consistency, permeability, signal for glucose and ease in handling. To determine the optimal relative saturation, a range of 38 to 45 relative \% was examined (Fig. 2). The maximal peak was obtained using layers with $41 \%$ relative saturation.

\subsection{Effect offlow rate}

The flow rates in FIA systems have significant effect on both the sample throughput and the detection limit. The disadvantages of lower flow rates are lower sample throughput and increased dispersion. On the other hand, using the higher flow rate more samples can be analyzed, the peaks become more narrow, but the detection limit gets higher at the same time. To determine the optimal flow rate, measurements were carried out using various flow rates in the range of 0.2 to $1.6 \mathrm{ml} \mathrm{min}{ }^{-1}$. In fact, the diffusion rate through the layers turned out to be more determinative than the flow rate. In a fairly wide range of flow rate $\left(0.4-0.9 \mathrm{ml} \mathrm{min}^{-1}\right)$ peaks were just the same. When the flow rate was slower, a larger proportion of the samples entered the layer, the enzyme-substrate conversion was more complete, but the peaks of hydrogen peroxide 
produced became wider and the measurement was very slow. At higher flow rates only a limited amount of substrate entered the layer, the peaks were much smaller. After analyzing the results, the optimal flow rate was found to be $0.7 \mathrm{ml} \mathrm{min}^{-1}$. In this case 20-30 samples were measured in an hour. (Data not shown.)

\subsection{Effect of enzyme quantity}

Layers were prepared at different enzyme concentrations. The enzyme added to partitioning systems was 12,16,20,24 and $28 \mathrm{U}$ respectively (from $0.47 \mathrm{mg}$ $\mathrm{GOD} / 1.38 \mathrm{mg}$ to $1.1 \mathrm{mg} \mathrm{GOD} / 1.38 \mathrm{mg}$ lyophilized drip). The interrelationship can be followed on Fig. 3, where the microscopic structures $(40 \times$ magnification $)$ of the gels containing increasing amount of $\operatorname{GOD}(0,12,20,28 \mathrm{U}$ respectively) are shown. On the photos it can be observed, that the size of vesicles became smaller and more indistinct with increasing enzyme amount. The layer prepared by $12 \mathrm{U}$ GOD was very thin, permitting only a few measurements. The layers with 16,20 and $24 \mathrm{U}$ GOD gave acceptable signals, while the last one (28 U) was thick, and not permeable enough.

\subsection{Effect of buffer $p H$}

To study the effect of buffer $\mathrm{pH}$ on the behavior of the enzymes entrapped in the membranes, the protein layers were always washed out with the proper buffer which was used for the measurements. The investigated range of $\mathrm{pH}$ was from 4.5-7.2. The results are shown in Fig. 4. According to results the peaks increased in the range of $4.8-5.4 \mathrm{pH}$. The optimal $\mathrm{pH}$ value for measuring glucose was found to be 5.1, the same as for dissolved enzyme. It is surprising because during the immobilization process the $\mathrm{pH}$ optimum of the enzymes usually changes (VÁRADI et al., 1995). Considering this result, it can be assumed that the enzyme molecules are in dissolved state in this chicken protein matrix and are only captured by the gel.

Fig. 3. Structure of protein gel layers containing GOD (a-d, 0, 12, 20, $28 \mathrm{U}$, GOD, respectively) $\rightarrow$ (Microscopic photo, 40x magnification.) 


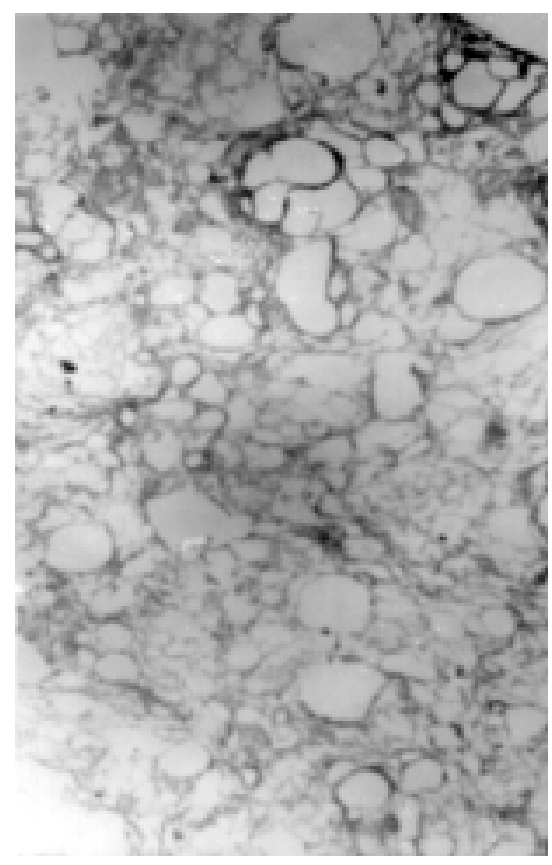

a

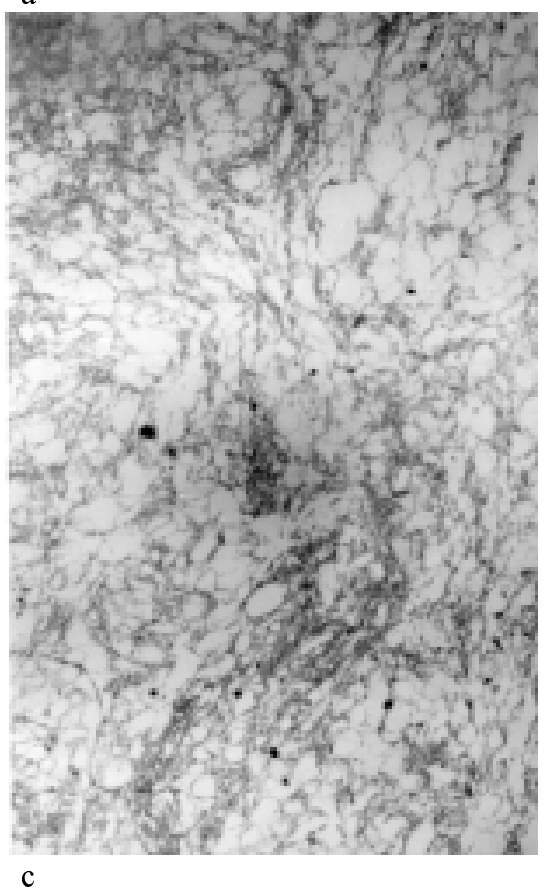

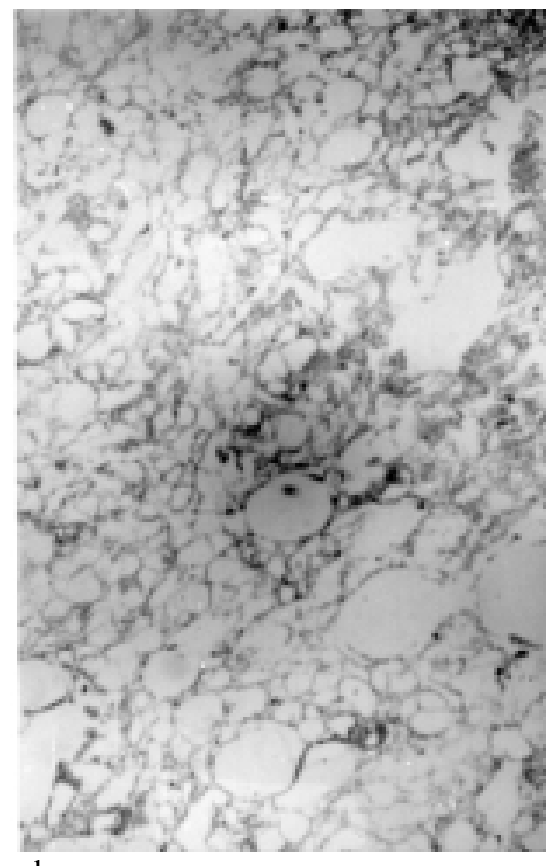

b

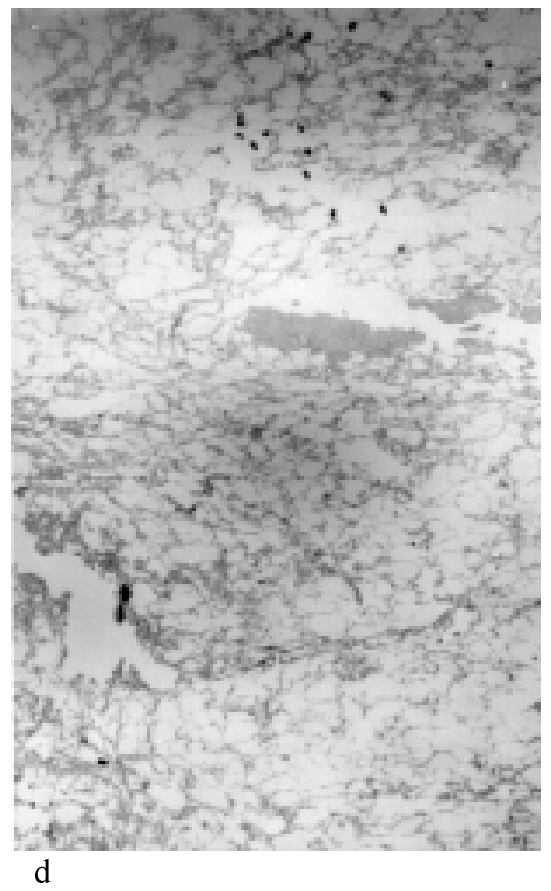

Acta Alimentaria 28, 1999 


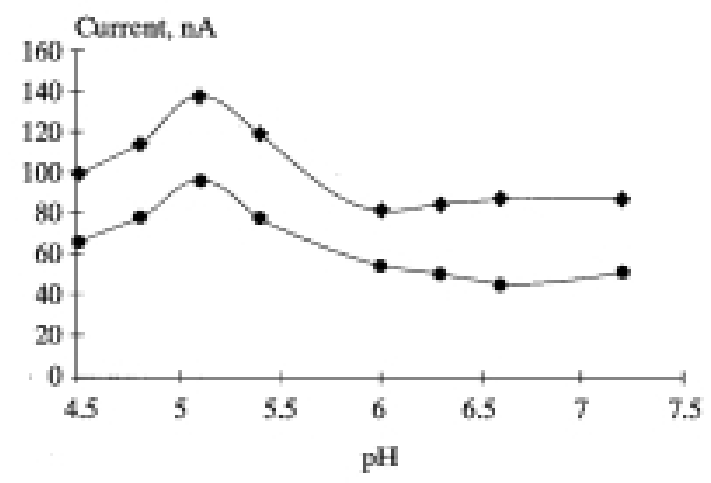

Fig. 4. Effect of pH. $\bullet: 5 \mathrm{mmol} 1^{-1}$ glucose $\bullet: 10 \mathrm{mmol}^{1^{-1}}$ glucose

\subsection{Effect of buffer concentration}

Since enzyme inhibition and the electrochemical reaction are influenced by the total ion concentration of buffer solutions, this effect had to be studied. Applying Michaelis buffers of $0.067-0.3 \mathrm{~mol} \mathrm{1}^{-1}$ concentration and of $\mathrm{pH} 5.1$, always the same buffers were used for washing the layers as for the measurements. The optimum of the buffer concentration was $0.2 \mathrm{~mol} \mathrm{1}^{-1}$. Using this buffer, the peaks became sharper, and the analysis of glucose could be performed in a relatively wide linear range from $0.5 \mathrm{mmol}^{-1}$ to $10 \mathrm{mmol} \mathrm{l}^{-1}$. (Data not shown.)

\subsection{Lifetime of the protein membranes and statistical parameters}

The biosensors were used intensively for ten days to determine the stability of the layer and the number of detectable samples (Fig. 5). After completing the cell it took only a few minutes until the amperometric current signal became permanent. In the next period of time the samples were measured with proper punctuality, the activity of the cell was stable, the rate of the reaction was determined by the diffusion. In the last part of the observed time the amperometric signal decreased quickly. By this time the rate of the reaction was already determined by the enzyme reaction. The enzyme cell ran down after measuring about 300 samples.

When injecting standard solutions the average of the measurements and the residual standard error within 15 samples were $80.6 \mathrm{nA}$ and $2.5 \mathrm{nA}$, respectively. 


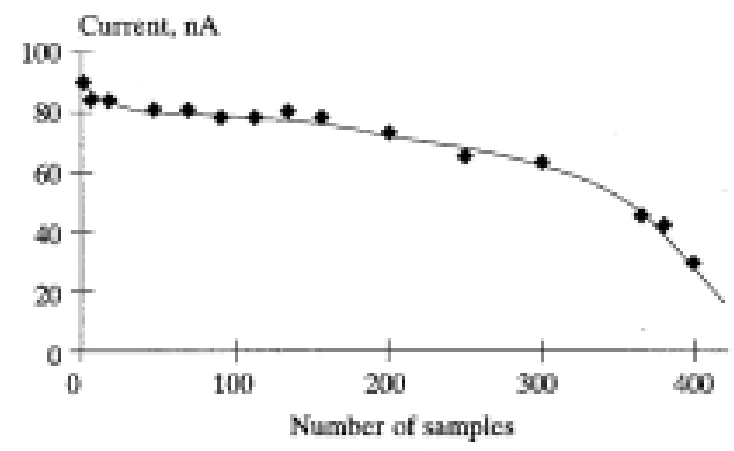

Fig. 5. Lifetime of the protein layer containing GOD

\subsection{Determination of glucose content in juice samples}

Glucose concentration of 10 juice samples was measured and compared with results obtained by the reference UV photometric method (D-Glucose UV-Test No. 716251 Boehringer, Mannheim). The average concentrations measured by both methods are shown in Fig. 6. The correlation between the two methods was very good, the correlation coefficient (r) was 0.992 .

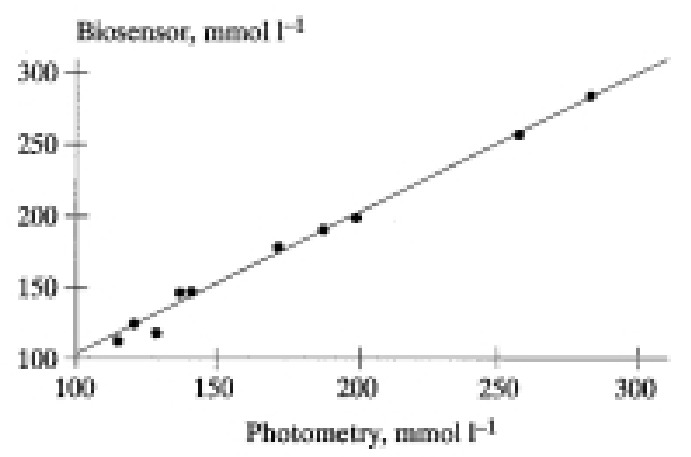

Fig. 6. Correlation between glucose measurement with reference method and with biosensor. (Correlation coefficient $\left.=0.993 ; r^{2}=0.986\right)$ 


\section{Conclusion}

Protein layers, containing glucose oxidase, were prepared by combining TPP with middle speed centrifugation (4500 g). Beyond entrapping the enzyme in its active state, the layer proved to be permeable to electroactive components such as hydrogen peroxide. The most effective layer could be prepared from chicken drip. The sensors constructed by protein layers prepared from chicken drip and glucose oxidase with their partitioning between water and organic phase, met the overall requirements for biosensors. An outstanding uniformity of layers containing GOD was achieved by strict control of the partitioning process and centrifugation. During the measurements we never found any microbial contamination in the protein layers used for entrapping the enzymes. The novel procedure elaborated is simple and fast. In the present work the enzymes bind to proteins of meat origin by only physical way giving the immobilized layer of the biosensor. On the basis of these results, it can be assumed, that enzymes which are immobilized together with proteins of meat origin by TPP preserve their original activity whereas layers usually prepared for biosensors containing enzymes which meet solubility criteria loose some of their activity during the covalent immobilization.

We would like to thank E. FODOR of the Frédéric Joliot-Curie National Research Institute for Radiobiology and Radiohygiene for the microscopic investigations.

This work was supported by the Hungarian Science Research Fund (OTKA T/017103, T/017306).

\section{References}

LOVRIEN, R. E., GOLDENSOPH, C., ANDERSON, P. C. \& ODEGAARD, B. H. (1987): Three-phase partitioning (TPP) via t-butanol: Enzyme separation from crudes - in: Protein purification: micro to macro. Alan R. Liss. Inc., pp. 131-148.

ODEGAARD, B. H., ANDERSON, P. C. \& LOVRIEN, R. E. (1984): Resolution of the multienzyme cellulose complex of Trichoderma reseei QM 9414. J. appl. Biochem., 156-183.

PENNY, I. F. (1975): Use of a centrifuging method to measure the drip of pork Longissimus dorsi slices before and after freezing and thawing. J. Sci. Fd. Agric., 226, 1593-1602.

PIKE, R. N. \& DENNISON, C. (1989): Protein fractionation by three-phase partitioning (TPP) in aqueous/tbutanol mixtures. Biotechnol. Bioengng., 33, 221-228.

SCHELlER, F. \& SCHUBERT, F. (1992): Biosensors. Elsevier Science Publishing Co., Amsterdam, pp. $248-251$.

SZAMOS, J. \& HOSCHKE, Á. (1992): Purification of horseradish peroxidase by three-phase partitioning (TPP). Acta Alimentaria, 21, 253-360.

SZAMOS, J., JÁNOS, A., TAMÁS, B. \& KISS, É. (1998): A novel partitioning method as a possible tool for investigating meat. I. Z. Lebensmittelunters $u$. Forsch. A, 206, 208-212.

VÁRADI, M., ADÁNYI, N. \& SZABÓ, E. E. (1995): Determining glucose content in juices with biosensor. Acta Alimentaria, 24, 365-377. 